\title{
CLINICAL SPECTRUM AND ATYPICAL PRESENTATIONS OF COVID-19 IN HOSPITALIZED CHILDREN IN A TERTIARY CARE HOSPITAL: PROSPECTIVE OBSERVATIONAL STUDY
}

\author{
Shweta Pathak, Monica Lazarus, Pawan Ghanghoriya. \\ Department of Pediatrics, NSCB Medical College Jabalpur, Madhya Pradesh, India.
}

\begin{abstract}
Background: Since December 2019, an outbreak of coronavirus disease 2019 (COVID-19) has spread globally. India is now $2^{\text {nd }}$ worst affected country after USA. In central India, little is known about the clinical spectrum and severity of COVID-19 in children.
\end{abstract}

Aim: To assess the clinical characteristics of hospitalized COVID-19 infected children below 14 years of age and to describe atypical presentations of COVID-19 in children.

Design: Prospective observational study

Setting: Tertiary care centre and a dedicated COVID hospital in central India.

Participants: All the children with RT-PCR confirmed COVID-19 (Nasopharyngeal or oropharyngeal swabs) or a positive SARS-CoV-2 antibody test between $14^{\text {th }}$ April to $30^{\text {th }}$ October 2020 were enrolled in this study. Clinical presentation, progression, course, and outcomes of these children were assessed.

Results: Total 45 children were admitted with COVID-19.The median age of children with COVID-19 was 5.5 years ( 3 days- 14 years). The cohort was predominantly male $(66.6 \%)$ and only $5(11 \%)$ children had co-morbidities ( 4 children had malnutrition and 1 had congenital heart disease). The route of transmission was either by close contact with family members with COVID-19 $33(73 \%)$ or a history of exposure to epidemic areas $33(73 \%)$. The most common presenting symptoms were fever in $16(35.5 \%)$, cough in $10(22 \%)$, breathing difficulty in $8(18 \%)$, nausea and vomiting in $8(18 \%)$ and seizures in $6(13.3 \%)$ patients. Twenty-three $(51 \%)$ children were asymptomatic, 8 $(17 \%)$ children had mild symptoms, $4(8.8 \%)$ had moderate disease and 10 children were admitted with severe/critical disease requiring admission in critical care unit. Of the severe/critical patients, septic shock with respiratory failure was seen in $4(8.8 \%)$, Guillain Barre Syndrome (GBS) in $1(2 \%)$, encephalitis in $2(4 \%)$, Kawasaki disease (KD) in $1(2 \%)$ and acute respiratory distress syndrome (ARDS) in $2(4 \%)$ children. Three $(6.6 \%)$ children died, and all were in the age group between 2-3 months. Out out of 10 critical patients, 8 had high neutrophil lymphocyte ratio (NLR), 6 had high d-dimers and high ferritin levels.

Conclusion: Our study shows that pediatrics patients with COVID-19 have a simple transmission mode, either by close contact with infected adults or by exposure to epidemic areas. Most children are asymptomatic. Atypical or severe manifestations can be seen in $22 \%$ of children and require intensive monitoring. Severe life-threatening illnesses in the form of ARDS, GBS, KD and other multisystem involvement are seen in these patients. Therefore, it is mandatory in current scenario to have a high degree of suspicion for COVID-19 in children admitted in pediatric intensive care units (PICUs) with an unexplained diagnosis, persistent fever and high levels of inflammatory markers.

CONTACT Dr Shweta Pathak

Email: drsp83@gmail.com

Address for Correspondence: Dr Shweta Pathak, H.N. 567, Anand colony, Baldav Bag, Jabalpur (M.P.) 482002, India.

(C)2020 Pediatric Oncall

\author{
ARTICLE HISTORY \\ Received 13 October 2020 \\ Accepted 5 December 2020 \\ KEYWORDS \\ COVID-19, children, clinical \\ features
}

\begin{abstract}
Introduction
Children and young people comprise only $1-2 \%$ of cases of novel coronavirus [COVID-19 (SARS-CoV-2)] worldwide. ${ }^{1,2,3}$ In contrast to other respiratory viruses, children seem to have a lower risk of infection than adults $^{4}$ and the vast majority of reported infections in children are mild or asymptomatic, with few recorded
\end{abstract}


childhood fatalities attributed to COVID-19. 5,6,7 Initial reports from China showed that only $0.6 \%$ of children with COVID-19 were critically ill. ${ }^{5}$

A severe disease phenotype has emerged in children that seems to be temporally associated with SARSCoV-2 infection. 8,9 The condition was first described in May 2020 in a cluster of children admitted to critical care in south London (UK), with evidence of a multisystem hyper inflammatory state with features similar to Kawasaki disease and toxic shock syndrome. ${ }^{9}$ These children needed inotropic support for refractory circulatory shock and mechanical ventilation for cardiovascular stabilization rather than respiratory failure. Similar cohorts have been reported in Italy and France. ${ }^{10,11}$ The World Health Organization (WHO) ${ }^{9}$ and the Royal College of Pediatrics and Child Health (RCPCH) have proposed preliminary case definitions. ${ }^{12}$ WHO uses the term multisystem inflammatory syndrome in children and adolescents temporarily related to COVID-19 (MIS-C), and the RCPCH describes this illness as pediatric inflammatory multisystem syndrome temporally associated with SARS-CoV-2 (PIMS-TS)..$^{9,12}$

We tried to characterize the features of Infants and children (aged $<14$ years) admitted to hospital in our hospital with laboratory confirmed SARS-CoV-2 infection. As our study enrolled patients prospectively from the beginning of the pandemic, we have also explored the clinical presentation, progression, course, and outcomes of children meeting the WHO preliminary case definition for MIS-C. ${ }^{9}$

\section{Methods \& Materials}

\section{Study design and Setting}

This is an ongoing prospective observational study in the department of Pediatrics, NSCB Medical College Jabalpur. The study was approved by the Institutional Ethics Committee. Informed consent was obtained from the parents before the inclusion of subjects into the study.

\section{Participants}

We present the data from children and young people aged less than 14 years on the date of hospital admission, enrolled into the study up to $30^{\text {th }}$ October 2020, For this report, we included only those children and young people who had positive RT-PCR test of upper respiratory tract swabs (nasopharyngeal and oropharyngeal swabs) for detection of SARS-CoV-2 nucleic acid for COVID-19 or a positive antibody tests.

\section{Data Collection and Analysis}

Demographic and baseline data (including co morbidities and regular medications taken) alongside data on symptoms (fever, cough, diarrhea, vomiting, malaise fatigue and seizure), co-morbidities mainly cardiac, respiratory diseases and severe acute malnutrition, clinical signs (including vital signs) during admission, laboratory and pathology investigations, treatments received while admitted, and outcome were collected onto case report forms. Data on illness progression and severity were collected on day 1 (admission/diagnosis), day 3 , day 6 , and day 9 , admission to critical care, and discharge/death.

Cases were classified as mild when there was no oxygen requirement, moderate with oxygen saturation 90-94\% at room air, severe and critical when there was central cyanosis or oxygen saturation of $<90 \%$ at room air, inability to breastfeed or drink, lethargy or unconsciousness, convulsions, acute respiratory distress syndrome (ARDS), septic shock or in multiorgan failure. ${ }^{13}$

Malnutrition was defined as stunting (low stature for age) and underweight (low weight for age), using the WHO definition of two or more $Z$ scores below the median. ${ }^{14}$ Severe acute malnutrition (SAM) was defined as a weight-for-height measurement of $70 \%$ or less below the median, or three standard deviations (SD) or more below the mean National Centre for Health Statistics reference values, the presence of bilateral pitting oedema of nutritional origin, or a mid-upper-arm circumference of less than $110 \mathrm{~mm}$ in children age 1-5 years. ${ }^{15}$ Dyspnea or respiratory distress was considered when respiratory rate was more than $60 / \mathrm{min}$ in children less than 2 months, more than $50 / \mathrm{min}$ in children 2 to 11 months, and more than $40 / \mathrm{min}$ in children 1-5 year of age. ${ }^{16}$ ARDS was defined as worsening respiratory symptoms 1 week after disease onset due to SARS CoV-2 with new opacities on chest imaging not explained by cardiac failure or volume overload and with a partial pressure of oxygen ( $\mathrm{PaO} 2)$ to fraction of inspired oxygen (FIO2) ratio $\leq 300 \mathrm{mmHg} .{ }^{14,15}$ MIS-C was defined as a child presenting with persistent fever, inflammation (neutrophilia, elevated CRP and lymphopenia) and evidence of single or multiorgan dysfunction (shock, cardiac, respiratory, renal, gastrointestinal or neurological disorder) with additional features. This may include children fulfilling full or partial criteria for Kawasaki disease (KD) excluding any other microbial cause, including bacterial sepsis, staphylococcal or streptococcal shock syndromes and infections associated with myocarditis. Antibody test for SARS-CoV-2 may be positive (90 percent), RT PCR may be positive in 10 percent cases. ${ }^{17}$

CT Chest was done only in children admitted for severe acute respiratory distress, and classified as no pneumonia, pneumonia+ and pneumonia ++ based on grading (Normal or $<25 \%$ as Grade I, $25-75 \%$ as Grade II/III and $75-100 \%$ as Grade IVA). ${ }^{14}$ Specific laboratory tests done only in moderate to severe cases included NLR (neutrophil lymphocyte ratio) [Normal: $<3.5$, significant $>5.5$ (pre steroids)], C-reactive protein (CRP) (Normal $<40 \mathrm{mg} / \mathrm{L}$, significant $>100$ and rising), Procalcitonin (significant $>1 \mathrm{ng} / \mathrm{ml}$ ), Troponin I (normal reference range is $0.00-0.40$ and significant $>0.41$ ), Ferritin (Normal $<500 \mathrm{ng} / \mathrm{mL}$, significant $>700$ and rising), d-dimer (Normal $0-500 \mathrm{ng} / \mathrm{ml}$, significant $>500$ ), LDH (Normal <300 U/L, significant >400 and rising), Interleukin 6 (IL6) [Normal $<4.8 \mathrm{pg} / \mathrm{mL}$, significant $>80$ and rising (before receiving anti IL6)].18

Treatment protocol followed in our institution was as follows ${ }^{17}$ :

\section{Mild disease}

1) Paracetamol/ Non-steroidal anti-inflammatory drugs (NSAIDS)

2) Zinc - $20 \mathrm{mg} /$ day (>6 months of age) once a day for 14 days, $10 \mathrm{mg} /$ day (<6 months of age) once a 
day for 14 days.

3) Vitamin C - 50-100 mg/day once a day for 7 days

No anti-viral.

Moderate to severe disease

1) Remdesivir - May be given as compassionate use in very critical patients. Dose $>3.5$ to $<40 \mathrm{~kg}-5 \mathrm{mg} /$ $\mathrm{kg}$ loading dose, then $2.5 \mathrm{mg} / \mathrm{kg}$ once daily $x 5$ days; $>40 \mathrm{~kg}$ - $200 \mathrm{mg}$ intravenous (IV) OD on Day 1 and $100 \mathrm{mg}$ IV OD $\times 4$ days.

2) Anticoagulation - In those with indwelling central or peripheral central venous catheters. Subcutaneous low molecular weight heparin (LMWH) in <2 months: $0.75 \mathrm{mg} / \mathrm{kg} /$ dose $\mathrm{q} 12 \mathrm{~h}$; $\geq 2$ months: $0.5 \mathrm{mg} / \mathrm{kg} /$ dose q12 h. For high risk, critically ill patient with hyper inflammatory state (Dose - <2 months: $1.5 \mathrm{mg} / \mathrm{kg} /$ dose q12 h; $\geq 2$ months: $1 \mathrm{mg} / \mathrm{kg} /$ dose q12 h - Anti-Xa factor target: $0.5-1 \mathrm{IU} / \mathrm{ml}) .^{9}$

3) Steroids:

Dexamethasone - $0.15 \mathrm{mg} / \mathrm{kg}$ once daily (Max: $6 \mathrm{mg}$ ) OD for 10 days or

Prednisolone - $1 \mathrm{mg} / \mathrm{kg}$ once daily (Max: $40 \mathrm{mg}$ ) x 10 days or

Methylprednisolone $-0.8 \mathrm{mg} / \mathrm{kg}$ once daily (Max: 32 mg) $x 10$ days

Pulse Methylprednisolone would be used in high-risk KD features, MIS-C - $10-30 \mathrm{mg} / \mathrm{kg} /$ day for $1-3$ days followed by $2 \mathrm{mg} / \mathrm{kg} /$ day for 10 days.

4) Intravenous immunoglobulin (IVIG) was used in patients with KD features and/or coronary artery changes, MIS-C

Dose - 2 g/kg, (max dose 100g) over 24 hours.
Statistical Analysis: Data were collected from healthcare records onto the case report forms. Data were collected on an electronic database and analyzed. We presented continuous variables as mean (SD) and categorical variables as number (\%).

\section{Results}

Total 45 children presented with COVID-19 accounting for $4 \%$ of all patients admitted in the hospital at that time. The median age of children with COVID-19 was 5.5 years ( 3 days -14 years). Only $3(6.6 \%)$ children had co-morbidities ( 2 children had SAM and 1 had congenital heart disease). Baseline clinical characteristics are depicted in Table 1 . The all cause in-hospital case fatality rate for COVID-19 was $6.6 \%$ (3/45), compared with $27 \%$ in the whole cohort of all ages over the same time. Twenty-three (51\%) children were asymptomatic, $8(17 \%)$ children had mild symptoms, $4(8.8 \%)$ had moderate disease and $10(22 \%)$ children were admitted with severe/critical disease requiring admission in critical care unit. Of the severe/critical patients, septic shock with respiratory failure was seen in $4(8.8 \%)$, Guillain barre syndrome in $1(2 \%)$, encephalitis in $2(4 \%)$, Kawasaki like disease in $1(2 \%)$ and acute respiratory distress syndrome (ARDS) in 2 (4\%) children. Table 2 depicts clinical and laboratory features of patients with atypical features. Table 3 depicts treatment and outcome of patients with severe/critical disease. Three (6.6\%) children who died were in the age group between 2-3 months. Two out of those 3 died within 12 hours of admission (a 3-monthold female with septicemia, meningitis and respiratory failure and a $2 \frac{1}{2}$ month old with failure to thrive with septicemia, metabolic acidosis with refractory shock).

Table 1. Baseline and clinical characteristics of children with COVID-19

\begin{tabular}{ll}
\hline Baseline characteristics & Number of patients (\%) \\
\hline Age & $15(33.3 \%)$ \\
1 years & $5(11.1 \%)$ \\
1 year - 5 years & $25(55 \%)$ \\
Gender & \\
Female & $15(23.3 \%)$ \\
Male & $30(66.6 \%)$ \\
History of exposure to epidemic area & $33(73 \%)$ \\
Family members with COVID-19 & $33(73 \%)$ \\
Fever & $16(35.5 \%)$ \\
Cough & $10(22 \%)$ \\
Nausea and vomiting & $8(18 \%)$ \\
Respiratory distress & $8(18 \%)$ \\
Seizures & $6(13.3 \%)$ \\
Quadriparesis & $1(2 \%)$ \\
Co-morbidities & \\
Malnutrition & $4(9 \%)$ \\
Congenital heart disease & $1(2 \%)$ \\
Oxygen by prongs & $10(22 \%)$ \\
Mechanical ventilation & $8(17.7 \%)$ \\
&
\end{tabular}


Table 2. Summary of clinical findings and investigations of critically ill children with atypical presentation

\begin{tabular}{|c|c|c|c|c|c|c|}
\hline Clinical Features & Case 1 & Case 2 & Case 3 & Case 4 & Case 5 & Case 6 \\
\hline Age/Gender & $9 \mathrm{yrs} / \mathrm{M}$ & $13 \mathrm{yrs} / \mathrm{F}$ & $2 \mathrm{mo} / \mathrm{F}$ & $10 \mathrm{yrs} / \mathrm{F}$ & 40 days/M & $13 \mathrm{yrs} / \mathrm{M}$ \\
\hline Exposure known/unknown & $\begin{array}{l}\text { Known } \\
\text { (father) }\end{array}$ & Unknown & $\begin{array}{l}\text { Known } \\
\text { (Parents) }\end{array}$ & Unknown & Unknown & Unknown \\
\hline Fever & Yes & Yes & Yes & Yes & Yes & Yes \\
\hline Vomiting & Yes & Yes & Yes & No & Yes & Yes \\
\hline Headache & No & Yes & No & No & No & Yes \\
\hline Seizures & Yes & Yes & Yes & No & Yes & Yes \\
\hline Cough & Yes & No & No & No & No & Yes \\
\hline Quadriparesis & No & No & No & $\begin{array}{l}\text { Yes } \\
\text { (Tran- } \\
\text { sient) }\end{array}$ & No & No \\
\hline $\begin{array}{l}\text { Total leucocyte count (cells/ } \\
\text { cumm) }\end{array}$ & 6300 & 42400 & 10000 & 13800 & 10900 & 41000 \\
\hline Platelet counts ( $\times 10^{9} / \mathrm{cumm}$ ) & 7.6 & 4.3 & 4.13 & 3.2 & 2.4 & 0.51 \\
\hline $\mathrm{N} / \mathrm{L}$ ratio & $>3.3$ & $>3.3$ & $<3.3$ & $>3.3$ & $>3.3$ & $>3.3$ \\
\hline CRP (mg/l) & 35.8 & 35 & 83 & 20 & 12 & 43 \\
\hline Ferritin (ng/ml) & 1089 & 989 & 353.20 & 853 & 350 & 1036 \\
\hline LDH (IU/L) & 203 & 350 & 342 & 342 & 250 & 373 \\
\hline Procalcitonin (ng/ml) & 0.025 & 0.02 & 0.10 & 0.02 & 10 & 71.2 \\
\hline D-dimer (ng/ml) & 1281 & 1000 & 965 & 1065 & 500 & 2000 \\
\hline Troponin I (ng/ml) & 0.01 & 0.02 & 0.01 & 0.02 & 0.01 & 0.01 \\
\hline Chest $X$ ray & Normal & Normal & Normal & Normal & Normal & Normal \\
\hline $\begin{array}{l}\text { Throat Swab for COVID-19 } \\
\text { RT-PCR }\end{array}$ & Positive & Negative & Negative & Negative & Positive & Negative \\
\hline COVID antibody & Negative & Positive & Positive & Positive & Negative & Positive \\
\hline Diagnosis & ARDS & $\begin{array}{l}\text { MIS-C } \\
\text { (Incom- } \\
\text { plete KD) }\end{array}$ & $\begin{array}{l}\text { MIS-C } \\
\text { with sep- } \\
\text { tic shock }\end{array}$ & $\begin{array}{l}\text { Guillain } \\
\text { Barre syn- } \\
\text { drome }\end{array}$ & $\begin{array}{l}\text { Septice- } \\
\text { mia }\end{array}$ & $\begin{array}{l}\text { Encephali- } \\
\text { tis, MIS-C }\end{array}$ \\
\hline
\end{tabular}

Note: MIS-C - multisystem inflammatory syndrome in children, N/L - Neutrophil/lymphocyte ratio, CRP - C-reactive protein, LDH - lactate dehydrogenase, PCT - procalcitonin, ARDS - Acute respiratory distress syndrome, KD - Kawasaki disease.

Table 3. Management and outcome of severe COVID infection in children

\begin{tabular}{|c|c|c|c|c|c|c|c|c|c|c|}
\hline $\begin{array}{l}\text { Age/ } \\
\text { Sex }\end{array}$ & Diagnosis & $\begin{array}{l}\text { Given } \\
\text { Remde- } \\
\text { sivir }\end{array}$ & $\begin{array}{l}\text { Co-mor- } \\
\text { bidities }\end{array}$ & $\begin{array}{l}\text { Giv- } \\
\text { en } \\
\text { Ste- } \\
\text { roid }\end{array}$ & $\begin{array}{l}\text { Giv- } \\
\text { en } \\
\text { IVIG }\end{array}$ & $\begin{array}{l}\text { Given } \\
\text { LMWH }\end{array}$ & $\begin{array}{l}\text { Me- } \\
\text { chan- } \\
\text { ical } \\
\text { venti- } \\
\text { lation }\end{array}$ & $\begin{array}{l}\text { Iono- } \\
\text { tropic } \\
\text { sup- } \\
\text { port }\end{array}$ & $\begin{array}{l}\text { Dura- } \\
\text { tion of } \\
\text { treat- } \\
\text { ment }\end{array}$ & $\begin{array}{l}\text { Out- } \\
\text { come }\end{array}$ \\
\hline $\begin{array}{l}13 \\
\text { yrs/F }\end{array}$ & $\begin{array}{l}\text { MIS- C (Incom- } \\
\text { plete KD) }\end{array}$ & No & No & Yes & Yes & No & Yes & Yes & $\begin{array}{l}10 \\
\text { days }\end{array}$ & $\begin{array}{l}\text { Recov- } \\
\text { ered }\end{array}$ \\
\hline 3 yrs/F & $\begin{array}{l}\text { Acute gastro- } \\
\text { enteritis with } \\
\text { shock }\end{array}$ & No & $\begin{array}{l}\text { Malnutri- } \\
\text { tion }\end{array}$ & Yes & No & No & Yes & Yes & $\begin{array}{l}10 \\
\text { days }\end{array}$ & $\begin{array}{l}\text { Recov- } \\
\text { ered }\end{array}$ \\
\hline
\end{tabular}




\begin{tabular}{|c|c|c|c|c|c|c|c|c|c|c|}
\hline $\begin{array}{l}40 \\
\text { days/M }\end{array}$ & Septicemia & No & $\begin{array}{l}\text { Malnutri- } \\
\text { tion }\end{array}$ & No & No & No & No & No & $\begin{array}{l}14 \\
\text { days }\end{array}$ & $\begin{array}{l}\text { Recov- } \\
\text { ered }\end{array}$ \\
\hline $2 \mathrm{mo} / \mathrm{F}$ & $\begin{array}{l}\text { MIS-C with shock } \\
\text { with respiratory } \\
\text { failure }\end{array}$ & Yes & No & Yes & Yes & No & Yes & Yes & $\begin{array}{l}46 \\
\text { hours }\end{array}$ & Died \\
\hline $\begin{array}{l}9 \\
\text { yrs/M }\end{array}$ & $\begin{array}{l}\text { MIS-C with shock } \\
\text { with respiratory } \\
\text { failure }\end{array}$ & Yes & No & Yes & Yes & Yes & Yes & Yes & $\begin{array}{l}11 \\
\text { days }\end{array}$ & $\begin{array}{l}\text { Recov- } \\
\text { ered }\end{array}$ \\
\hline $3 \mathrm{mo} / \mathrm{F}$ & $\begin{array}{l}\text { Meningitis with } \\
\text { shock and respi- } \\
\text { ratory failure }\end{array}$ & No & $\begin{array}{l}\text { Malnutri- } \\
\text { tion }\end{array}$ & Yes & No & No & Yes & Yes & $\begin{array}{l}11 \\
\text { hours }\end{array}$ & Died \\
\hline $2 \mathrm{mo} / \mathrm{F}$ & $\begin{array}{l}\text { Sepsis with CCF, } \\
\text { shock and respi- } \\
\text { ratory failure }\end{array}$ & No & $\begin{array}{l}\text { Malnutri- } \\
\text { tion with } \\
\text { CHD }\end{array}$ & Yes & No & No & Yes & Yes & $\begin{array}{l}12 \\
\text { hours }\end{array}$ & Died \\
\hline $\begin{array}{l}13 \\
\text { yrs/M }\end{array}$ & $\begin{array}{l}\text { MIS-C with en- } \\
\text { cephalitis with } \\
\text { respiratory failure }\end{array}$ & No & No & Yes & No & Yes & Yes & Yes & $\begin{array}{l}14 \\
\text { Days }\end{array}$ & $\begin{array}{l}\text { Recov- } \\
\text { ered }\end{array}$ \\
\hline $\begin{array}{l}10 \\
y r s / F\end{array}$ & $\begin{array}{l}\text { MIS-C with en- } \\
\text { cephalitis with } \\
\text { respiratory failure }\end{array}$ & No & No & Yes & No & Yes & Yes & Yes & $\begin{array}{l}10 \\
\text { Days }\end{array}$ & $\begin{array}{l}\text { Recov- } \\
\text { ered }\end{array}$ \\
\hline $\begin{array}{l}10 \\
\text { yrs/F }\end{array}$ & $\begin{array}{l}\text { Guillain Barre } \\
\text { syndrome with } \\
\text { respiratory failure }\end{array}$ & No & No & Yes & Yes & No & Yes & Yes & 4 Days & $\begin{array}{l}\text { On } \\
\text { treat- } \\
\text { ment }\end{array}$ \\
\hline
\end{tabular}

Note: LMWH - low molecular weight heparin, MIS-C - multisystem inflammatory syndrome in children, KD - Kawasaki disease, CHD - Congenital heart disease, IVIG - intravenous immunoglobulin.

\section{Discussion}

Most of the COVID-19 infections are asymptomatic in children as well as adults and many of them are not reported. ${ }^{19,20}$ Therefore, we confined our study to symptomatic cases only. Pediatric observational studies published early in the spread across China reported similar clinical findings with fever being the most common symptom followed by cough and sore throat. ${ }^{19}$ In our study too, the main clinical features of COVID-19 in children were fever, cough, nausea, vomiting. Among critically ill children most common complaints were fever, breathing difficulty and seizures. Four patients out of 10 with severe COVID-19 in our study presented initially as viral encephalitis and therefore had seizures as a common complaint. The severe disease and critical disease (ARDS, respiratory failure, shock, myocardial failure, and multiorgan dysfunction) are less frequent in children (1-3\%) as compared to adults (10-30\%). ${ }^{20}$ A recent meta-analysis has also shown that most of the patients have mild to moderate disease (96\%) with only $1 \%$ of all the symptomatic pediatric cases being critically sick. ${ }^{20}$ In our study also, most patients were asymptomatic but $22 \%$ had atypical or severe disease. Since our study is a hospital-based study and most of the mild and asymptomatic cases were not admitted therefore we saw slightly increased number of cases with severe/ critical disease. Various hypotheses have been proposed for the lesser disease severity in children ${ }^{21}$, though a definite answer is still awaited. Similarly, the mortality associated with COVID-19 is much lower in the pediatric population (less than $1 \%$ ) than that reported in adults $(5-15 \%){ }^{21}$ However, In a cross-sectional study of 46
North American pediatric intensive care units (PICUs), between March 14 and April 3, 2020, 48 children were admitted to 14 PICUs in the US and none in Canada of which $73 \%$ presented with respiratory symptoms, and $38 \%$ required invasive ventilation, and the hospital mortality rate was $4.2 \% .{ }^{22}$ In our study the mortality rate was $6.6 \%$ as it was a hospital-based study and out of 10 critically ill children, almost all children required inotropic support, 9 required mechanical ventilation and other life supportive treatment. Mortality in our study was only seen in those who died within 12 hours of admission. Co-morbidities play a major role in terms of severity of the disease especially malnutrition which is a most seen co-morbidity as a risk factor for severe COVID-19. ${ }^{23}$ In children, malnutrition is known to foster infections; in our study we have seen deaths in younger infants with associated malnutrition as co morbidity. Four out of 10 patients who developed severe disease had associated malnutrition therefore can be considered as an important risk factor for severe disease. However more data is needed to clarify the association of malnutrition and other co-morbid condition with mortality in children with COVID-19.

In our study, patients acquired COVID-19 by clear transmission routes, including close contact with family members, a history of exposure to epidemic areas, or both. No other sources, such as a hospital stay or unclear routes of transmission, were identified. This situation could be altered if COVID-19 persists for a long time in an area with increased risk for communityacquired infections which is not yet started in India. ${ }^{24}$ The hematological profile of adults with COVID-19 has 
demonstrated leucopenia with associated neutrophilia, lymphopenia, eosinopenia and thrombocytopenia. Also, higher NLR have been associated with severe disease and used for prognostication. ${ }^{25,26}$ In our study out of 10 critical patients, 8 had high NLR, 6 had high d-dimers and high ferritin levels suggestive that high NLR, high ferritin, high d-dimer and LDH levels are the markers of severe disease. High CRP values have now become synonymous with severe COVID-19 infection among adults as seen in majority of the studies. ${ }^{26}$ In our study we had seen high CRP values with a mean of $35 \mathrm{mg} / \mathrm{l}$ and ranging from 12 to 85 in all children with moderate to severe disease.

MIS-C is characterized by an unusual febrile illness with associated features suggestive of Kawasaki disease, toxic shock syndrome, myocardial dysfunction, or multi-organ failure. ${ }^{3}$ MIS-C is affecting only $0.6 \%$ of patients $<21$ years of age infected with SARS Cov-2 ${ }^{27,28}$ and there are limitations in its recognition and diagnosis. ${ }^{28}$ In our study, 5(11\%) patients were diagnosed as MIS-C based on persistent fever, high inflammatory markers, and a positive antibody test for COVID-19. Whitaker, et $a^{29}$ have proposed three clinical patterns of PIMS-TS presentation viz, those with shock and cardiac involvement, those with fever and elevated inflammatory markers without features of KD, and those who fulfilled diagnostic criteria for KD. In our series, while only one patient fulfilled diagnostic criteria for classical $\mathrm{KD}^{30}$, there is significant epidemiological evidence that MIS-C is distinct from KD. Children with MIS-C are older and sicker as compared with those of classical KD. ${ }^{31}$ Feldstein, et al. ${ }^{31}$ have observed $50 \%$ MIS-C patients present with cardiovascular shock leading to vasopressor or inotropic support as compared to only $5 \%$ of children with KD in the United States. In the US MIS-C series, IVIG (77\%) and systemic glucocorticoids (49\%) were used in most patients. ${ }^{31}$ In our series, among critical patients $90 \%$ received steroids and $40 \%$ received IVIG, and $90 \%$ required inotropic support and mechanical ventilation. The relatively lower usage of IVIG can be attributed to the high cost of this treatment, which unfortunately is often a deciding factor for treatment decisions in our population.

In our study of 45 hospitalized children with COVID-19 infection, 10 children presented with severe/critical disease and 8 of those 10 had an unknown exposure and did not even have any respiratory complaint therefore the diagnosis was made based on their persistent fever, no response to the treatment given and high levels of inflammatory markers. Only 4 out of the 10 had positive RT-PCR test for COVID-19 while remaining 6 critical children had positive antibody test for COVID-19. Thus, atypical COVID-19 should be suspected in children with persistent fever and high levels of inflammatory markers.

\section{Conclusion}

Our study shows that pediatrics patients with COVID-19 have a simple transmission mode, either by close contact with infected adults or by exposure to epidemic areas. Most children are asymptomatic. Atypical or severe manifestations can be seen in $22 \%$ of children and require intensive monitoring. Severe life-threatening illnesses in the form of ARDS, GBS, KD and other multisystem involvement are seen in these patients. Therefore, it is mandatory in current scenario to have a high degree of suspicion for COVID-19 in children admitted in pediatric intensive care units (PICUs) with an unexplained diagnosis, persistent fever and high levels of inflammatory markers.

\section{Acknowledgement}

We would like to acknowledge our respected HODs Dr Avyact Agrawal and Dr Pawan for their guidance, our colleagues Dr Pratibha Bamne, Dr Ravi Uikey, Dr Akhilendra Parihar (senior residents and postgraduate residents) for their constant efforts in the management of COVID children. Special thanks to Dr Shashank Pandey for literature search.

\section{Compliance with Ethical Standards Funding None \\ Conflict of Interest None}

\section{References:}

1. Wu Z, McGoogan JM. Characteristics of and Important Lessons from the Coronavirus Disease 2019 (COVID-19) Outbreak in China: Summary of a Report of 72314 Cases From the Chinese Center for Disease Control and Prevention. JAMA. 2020;323:1239-1242.

2. CDC COVID-19 Response Team. Coronavirus Disease 2019 in Children - United States, February 12-April 2, 2020. MMWR Morb Mortal Wkly Rep. 2020 Apr 10;69(14):422426.

3. Perikleous E, Tsalkidis A, Bush A, Paraskakis E. Coronavirus global pandemic: An overview of current findings among pediatric patients. Pediatr Pulmonol. 2020;55:3252-3267.

4. Viner RM, Mytton OT, Bonell C, Melendez-Torres GJ, Ward J, Hudson L, et al. Susceptibility to SARS-CoV-2 Infection Among Children and Adolescents Compared With Adults: A Systematic Review and Meta-analysis. JAMA Pediatr. 2020:e204573.

5. Dong $Y$, Mo X, Hu Y, Qi X, Jiang F, Jiang Z, Tong S. Epidemiology of COVID-19 Among Children in China. Pediatrics. 2020;145:e20200702.

6. Lu X, Zhang L, Du H, Zhang J, Li YY, Qu J, et al; Chinese Pediatric Novel Coronavirus Study Team. SARS-CoV-2 Infection in Children. N Engl J Med. 2020;382:1663-1665

7. Liu W, Zhang Q, Chen J, Xiang R, Song H, Shu S, et al. Detection of COVID-19 in Children in Early January 2020 in Wuhan, China. N Engl J Med. 2020;382:1370-1371.

8. Riphagen S, Gomez X, Gonzalez-Martinez C, Wilkinson N, Theocharis P. Hyperinflammatory shock in children during COVID-19 pandemic. Lancet. 2020;395:1607-1608.

9. World Health Organization (WHO). Multisystem inflammatory syndrome in children and adolescents temporally related to COVID-19. 2020. Available at URL: https://www.who.int/news-room/commentaries/detail/ multisystem-inflammatory-syndrome-in-children-andadolescents-with-COVID-19. Accessed on 1st December 2020.

10. Verdoni L, Mazza A, Gervasoni A, Martelli L, Ruggeri $M$, Ciuffreda $M$, et al. An outbreak of severe Kawasakilike disease at the Italian epicentre of the SARS-CoV-2 epidemic: an observational cohort study. Lancet. 
$2020 ; 395: 1771-1778$

11. Toubiana J, Poirault C, Corsia A, Bajolle F, Fourgeaud J, Angoulvant $F$, et al. Kawasaki-like multisystem inflammatory syndrome in children during the COVID-19 pandemic in Paris, France: prospective observational study. BMJ. 2020;369:m2094

12. Royal College of Paediatrics and Child Health. Paediatric multisystem inflammatory syndrome temporally associated with COVID-19 (PIMS) - guidance for clinicians. Available at URL: https://www.rcpch.ac.uk/resources/paediatricmultisystem-inflammatory-syndrome-temporallyassociated-COVID-19-pims-guidance. Accessed on 1st December 2020.

13. Ravikumar N, Nallasamy K, Bansal A, Angurana SK, Basavaraja GV, Sundaram M, et al; Intensive Care Chapter of Indian Academy of Pediatrics. Novel Coronavirus 2019 (2019-nCoV) Infection: Part I - Preparedness and Management in the Pediatric Intensive Care Unit in Resource-limited Settings. Indian Pediatr. 2020;57:324334

14. World Health Organization (WHO). Child Growth Standards: Length/height-for-age, weight-for-age, weight-for-length, weight-for-height and body mass index-for-age: methods and development. Available from URL: https://www.who. int/childgrowth/standards/Technical_report.pdf. Accessed on 14 Jan 2019.

15. World Health Organization (WHO. Community-Based Management of Severe Acute Malnutrition. Available at URL: https://www.who.int/nutrition/topics/ Statement_ community_based_man_sev_acute_mal_eng.pdf. Accessed on 1st December 2020.

16. World Health Organization (WHO). Handbook IMCI. Integrated management of childhood illness. Available from URL: https://apps.who.int/iris/ bitstream/handle/10665/42939/9241546441.pdf? sequence $=1$ \&isAllowed $=y$. Accessed on 1 st December 2020.

17. Government of India. Ministry of Health and Family Welfare. CLINICAL MANAGEMENT PROTOCOL: COVID-19 Available from URL: https://www.mohfw. gov.in/pdf/ UpdatedClinicalManagementProtocol forCOVID19dated03072020.pdf. Assessed on 15 July 2020.

18. Uptodate. Coronavirus disease 2019 (COVID-19): Multisystem inflammatory syndrome in children. Available from URL https://www.uptodate.com/contents/ coronavirus-disease-2019-COVID-19-multisysteminflammatory- syndrome-in-children-mis-c-managementand-outcome. Assessed on 17 July 2020.

19. CHKD Treatment Guideline for COVID-19 in Children. Available from URL: https://www.chkd.org/uploadedFiles/ Documents/COVID-19/CHKD\%20COVID\%2019\%20 treatment\%20guideline.pdf. Assessed on 17 July 2020.

20. Henry BM, de Oliveira MHS, Benoit S, Plebani M, Lippi G. Hematologic, biochemical and immune biomarker abnormalities associated with severe illness and mortality in coronavirus disease 2019 (COVID-19): a meta-analysis. Clin Chem Lab Med. 2020;58:1021-1028.

21. Qiu H, Wu J, Hong L, Luo Y, Song Q, Chen D. Clinical and epidemiological features of 36 children with coronavirus disease 2019 (COVID-19) in Zhejiang, China: an observational cohort study. Lancet Infect Dis. 2020;20:689-696.

22. Shekerdemian LS, Mahmood NR, Wolfe KK, Riggs BJ, Ross CE, McKiernan CA, et al; International COVID-19 PICU Collaborative. Characteristics and Outcomes of Children With Coronavirus Disease 2019 (COVID-19) Infection Admitted to US and Canadian Pediatric Intensive Care Units. JAMA Pediatr. 2020;174:868-873.

23. Meena J, Yadav J, Saini L, Yadav A, Kumar J. Clinical Features and Outcome of SARS-CoV-2 Infection in Children: A Systematic Review and Meta-analysis. Indian Pediatr. 2020;57:820-826.

24. World Health Organization (WHO). Transmission of SARS-CoV-2: implications for infection prevention precautions. Available at URL: https://www.who.int/ news-room/commentaries/detail/ transmission-of-sarscov-2-implications-for-infection-prevention-precautions. Accessed on 1st December 2020.

25. Lagunas-Rangel FA. Neutrophil-to-lymphocyte ratio and lymphocyte-to-C-reactive protein ratio in patients with severe coronavirus disease 2019 (COVID-19): A metaanalysis. J Med Virol. 2020:10.1002/jmv.25819.

26. Wang L. C-reactive protein levels in the early stage of COVID-19. Med Mal Infect. 2020;50:332-334.

27. Dufort EM, Koumans EH, Chow EJ, Rosenthal EM, Muse A, Rowlands J, et al; New York State and Centers for Disease Control and Prevention Multisystem Inflammatory Syndrome in Children Investigation Team. Multisystem Inflammatory Syndrome in Children in New York State. N Engl J Med. 2020;383:347-358.

28. Levin M. Childhood Multisystem Inflammatory Syndrome - A New Challenge in the Pandemic. N Engl J Med. 2020;383:393-395

29. Whittaker E, Bamford A, Kenny J, Kaforou M, Jones CE, Shah P, et al; PIMS-TS Study Group and EUCLIDS and PERFORM Consortia. Clinical Characteristics of 58 Children With a Pediatric Inflammatory Multisystem Syndrome Temporally Associated With SARS-CoV-2. JAMA. 2020;324:259-269.

30. Acharyya BC, Acharyya S, Das D. Novel Coronavirus Mimicking Kawasaki Disease in an Infant. Indian Pediatr. 2020;57:753-754.

31. Feldstein LR, Rose EB, Horwitz SM, Collins JP, Newhams $\mathrm{MM}$, Son MBF, et al; Overcoming COVID-19 Investigators; CDC COVID-19 Response Team. Multisystem Inflammatory Syndrome in U.S. Children and Adolescents. N Engl J Med. 2020;383:334-346. 